\title{
Salinity Tolerance of Cleopatra Mandarin and Carrizo Citrange Citrus Rootstock Seedlings Is Affected by $\mathrm{CO}_{2}$ Enrichment during Growth
}

\author{
Francisco García-Sánchez ${ }^{1}$ and J.P. Syvertsen ${ }^{2}$ \\ University of Florida, IFAS, Citrus Research and Education Center, 700 Experiment Station Road, \\ Lake Alfred, FL 33850
}

\begin{abstract}
Additional IndeX words. $\mathrm{Ca}^{2+}, \mathrm{Cl}^{-}, \mathrm{CO}_{2}$ assimilation, leaf dry weight per area, $\mathrm{N}, \mathrm{Na}^{+}$, shoot/root ratio, water relations
Abstract. Three-month-old citrus rootstock seedlings of the Cl-excluder Cleopatra mandarin (Citrus reticulata Blanco) and the $\mathrm{Cl}$-accumulator Carrizo citrange $\left[C\right.$. sinensis $\left(\mathbf{L}_{\text {. }}\right)$ Osb. $\times$ Poncirus trifoliata L.] were fertilized with nutrient solution with or without additional $50 \mathrm{~mm} \mathrm{NaCl}$ and grown at either ambient $\mathrm{CO}_{2}\left(360 \mu \mathrm{L} \cdot \mathrm{L}^{-1}\right)$ or elevated $\mathrm{CO}_{2}(700$ $\left.\mu \mathrm{L} \cdot \mathrm{L}^{-1}\right)$ in similar controlled environment greenhouses for 8 weeks. Elevated $\mathrm{CO}_{2}$ increased plant growth, shoot/root ratio, leaf dry weight per area, net assimilation of $\mathrm{CO}_{2}$, chlorophyll, and water-use efficiency but decreased transpiration rate. Elevated $\mathrm{CO}_{2}$ decreased leaf $\mathrm{Ca}^{2+}$ and $\mathrm{N}$ concentration in non-salinized Cleopatra. Salinity increased leaf $\mathrm{Cl}-$ and $\mathrm{Na}^{+}$in both genotypes. Carrizo had higher concentrations of $\mathrm{Cl}$ but lower $\mathrm{Na}^{+}$in leaves than $\mathrm{Cleopatra}$. Salinity decreased plant growth, shoot/root ratio, net gas exchange, water use, and root $\mathrm{Ca}^{+2}$ but increased root $\mathrm{N}$ in both genotypes regardless of $\mathrm{CO}_{2}$ level. Neither salinity nor elevated $\mathrm{CO}_{2}$ affected leaf chlorophyll fluorescence (Fv/Fm). Carrizo had higher Fv/Fm, leaf gas exchange, chlorophyll, N, and $\mathrm{Ca}^{2+}$ than Cleopatra. Salinity-induced decreases in leaf osmotic potential increased leaf turgor especially at elevated $\mathrm{CO}_{2}$. The increase in leaf growth at elevated $\mathrm{CO}_{2}$ was greater in salinized than in nonsalinized Carrizo but was similar in Cleopatra seedlings regardless of salt treatment. In addition, salinity decreased water-use efficiency more at elevated $\mathrm{CO}_{2}$ than at ambient $\mathrm{CO}_{2}$ in Cleopatra but not in Carrizo. Elevated $\mathrm{CO}_{2}$ also decreased leaf $\mathrm{Cl}_{-}^{-}$and $\mathrm{Na}^{+}$in Carrizo but tended to increase both ions in Cleopatra leaves. Based on leaf growth, water-use efficiency and salt ion accumulation, elevated $\mathrm{CO}_{2}$ increased salinity tolerance in the relatively salt-sensitive Carrizo more than in the salt-tolerant Cleopatra. In salinized seedlings of both genotypes, $\mathrm{Cl}$ and $\mathrm{Na}^{+}$concentration changes in response to $\mathrm{eCO}_{2}$ in leaves vs. roots were generally in opposite directions. Thus, the modifications of citrus seedling responses to salinity by the higher growth and lower transpiration at elevated $\mathrm{CO}_{2}$ were not only species dependent, but also involved whole plant growth and allocations of $\mathrm{Na}^{+}$and $\mathrm{Cl}$.
\end{abstract}

Based mostly on the accumulation of chlorides in leaves, citrus species are considered salt sensitive (Maas, 1990; Shalhevet and Levy, 1990). There are a variety of mechanisms that contribute to salt tolerance including compartmentation of toxic salt ions in cell vacuoles (Yeo, 1998), accumulation of balancing osmotic ions in the cytoplasm (Hare et al., 1998), the ability to reduce the $\mathrm{Cl}^{-}$and/or $\mathrm{Na}^{+}$uptake by roots (Walker and Douglas, 1983) and the lack of transport of $\mathrm{Cl}^{-}$and/or $\mathrm{Na}^{+}$to the shoot (Bañuls et al., 1990; Chen, 1992; Zekri, 1991). In citrus plants, $\mathrm{Cl}^{-}$influx and accumulation have been shown to be linked to water absorption and transpiration (Castle and Krezdorn, 1975; Syvertsen et al., 1989). Citrus rootstocks differ widely in their tolerance to soil salinity (Levy and Syvertsen, 2004). The relatively chloride-tolerant citrus rootstock Cleopatra mandarin transpires less water per unit leaf area than the chloride-sensitive rootstock Carrizo citrange (Moya et al., 1999, 2003). Since rapidly growing plants usually use more water than slower growing plants, is not clear whether accumulation of $\mathrm{Na}^{+}$and $\mathrm{Cl}^{-}$are related to growth and/or water use.

In many physiological studies, inhibition of plant growth by salinity has been related to a reduction in photosynthesis (Munns,

Received for publication 11 Apr. 2005. Accepted for publication 29 June 2005 We gratefully acknowledge Jill Dunlop and Eva Ros for skilled technical assistance. This research was supported by a fellowship from the Ministerio de Educación, Cultura y Deportes of Spain (AGL2003-08502-CO4-02/AGR) and the Florida Agricultural Experiment Station. Approved for publication as Journal Series No. R-10825.

'Present address: Centro de Edafologia y Biologia Aplicada del Segura. Consejo Superior de Investigaciones Cientificas. Campus Universitario de Espinardo. Espinardo. 30100. Murcia. Spain.

${ }^{2}$ Corresponding author, Email: jmsn@crec.ifas.ufl.edu
1993). This reduction could be caused by osmotic stress and/or the accumulation of toxic ions (Walker et al., 1993). Although osmotic stress almost always reduces plant growth, osmotic adjustment can be sufficient to offset the reductions in leaf water potential thereby maintaining or even increasing leaf turgor pressure in salt-treated plants (Bañuls and Primo-Millo, 1992; Lloyd et al., 1987a, 1990). There are good correlations between the reduction in $\mathrm{CO}_{2}$ assimilation $\left(\mathrm{A}_{\mathrm{CO} 2}\right)$ and increased concentration of leaf Cl- (Bañuls and Primo-Millo, 1992; Garcia-Legaz et al., 1993), but others have found such correlations with leaf $\mathrm{Na}^{+}$(GarciaLegaz et al., 1993; Walker et al., 1993) or with both $\mathrm{Cl}^{-}$and $\mathrm{Na}^{+}$ (Garcia-Sanchez et al., 2002; Lloyd et al., 1987b). The relative importance of $\mathrm{Cl}^{-}$and $\mathrm{Na}^{+}$limitations on $\mathrm{A}_{\mathrm{CO} 2}$ may be related to levels of $\mathrm{Ca}^{+2}$ in leaves as high $\mathrm{Ca}^{+2}$ can mitigate negative effects of $\mathrm{Na}^{+}$(Grattan and Grieve, 1992). Osmotic vs. toxic ion limitations on $\mathrm{A}_{\mathrm{CO} 2}$ and growth as well as $\mathrm{NaCl}$ effects on leaf $\mathrm{N}$ and $\mathrm{Ca}^{+2}$ balances in plants, remain active areas of research in citrus (Levy and Syvertsen, 2004).

High atmospheric $\mathrm{CO}_{2}$ concentrations stimulate photosynthesis by increasing the rate of carboxylation and decreasing the oxygenation rate of Rubisco (Bowes, 1991; Yelle et al., 1989). In addition, elevated $\mathrm{CO}_{2}\left(\mathrm{eCO}_{2}\right)$ increases water-use efficiency by reducing stomatal conductance and water use while increasing growth and $\mathrm{A}_{\mathrm{CO} 2}$ of leaves (Chen and Lenz, 1997; Drake et al, 1997). Thus, growing plants at $\mathrm{eCO}_{2}$ offers a mechanism to separate plant growth from water use, which are normally tightly coupled. Even salt-stressed plants generally grow more at elevated $\mathrm{CO}_{2}$ than at ambient levels of $\mathrm{CO}_{2}$ (Ball and Munns, 1992; Nicolas et al., 1993). If water use and salt uptake are indeed linked (Moya et al., 2003), then increasing water-use efficiency 
in $\mathrm{eCO}_{2}$ should result in reduced rates of salt accumulation in the leaves. We tested the hypothesis that salinity tolerance of citrus rootstock seedlings would be increased when grown in $\mathrm{eCO}_{2}$. We compared responses to soil $\mathrm{NaCl}$ of seedlings of Carrizo and Cleopatra in order to yield insights into mechanisms of salinity tolerance in citrus.

\section{Materials and Methods}

Plant culture. Two-month-old seedlings of Cleopatra mandarin and Carrizo citrange were grown individually in 1.5L containers filled with autoclaved Candler fine sand soil. The plants were watered three times per week with a dilute solution of a complete fertilizer $(8 \mathrm{~N}-0.88 \mathrm{P}-6.64 \mathrm{~K})$ plus iron-chelate $(6 \%)$. The volume of nutrient solution was sufficient to leach from the bottom of all pots to avoid any build up of salts. Seedlings received $21 \mathrm{mg}$ of $\mathrm{N}$ per week and were grown in an unshaded greenhouse made of clear double-walled polycarbonate under natural photoperiods. When the plants were 3 months old, half were moved to an identical greenhouse which was supplied with additional $\mathrm{CO}_{2}$ monitored with an infrared gas analyzer (S-151; Qubit Systems, Kingtons, Ont., Canada). The $\mathrm{eCO}_{2}$ concentration was maintained at about twice ambient $\left(700 \pm 20 \mu \mathrm{L} \cdot \mathrm{L}^{-1}\right)$ while the other greenhouse was maintained at ambient $\mathrm{CO}_{2}$ concentration $\left[\mathrm{aCO}_{2}\left(360 \pm 20 \mu \mathrm{L} \cdot \mathrm{L}^{-1}\right)\right]$. Except for atmospheric $\mathrm{CO}_{2}$ concentrations, the two greenhouses had very similar growth conditions. Maximum photosynthetic active radiation [PAR (LI170; LI-COR, Lincoln, Nebr.)] measured above the plants was $1500 \mu \mathrm{mol} \cdot \mathrm{m}^{-2} \cdot \mathrm{s}^{-1}$, average day/night temperature was $\approx 36 / 21^{\circ} \mathrm{C}$ and relative humidity varied daily from $40 \%$ to $100 \%$.

The salt treatment was begun at the same time as the supplemental $\mathrm{CO}_{2}$ treatment by adding an additional $10 \mathrm{~mm} \mathrm{NaCl}$ in the irrigation water each day to give a final $\mathrm{NaCl}$ concentration of $50 \mathrm{~mm}$. Salt and $\mathrm{eCO}_{2}$ treatments continued for 8 weeks. Plants were randomized within the greenhouses every week to avoid any potential positional effects. The experimental design was a $2 \times 2 \times 2$ factorial of two rootstocks $\times$ two $\mathrm{CO}_{2}$ treatments $(360$ and $\left.700 \mu \mathrm{L} \cdot \mathrm{L}^{-1}\right) \times$ two salt treatments $(0$ and $50 \mathrm{~mm} \mathrm{NaCl})$ with eight replicate plants in each treatment.

Water RELATIONS AND GAS EXCHANGE. About 7 weeks after initiating the salt and $\mathrm{CO}_{2}$ treatments, gas exchange and water relations measurements were made on fully expanded leaves chosen from the mid-shoot area of each seedling in each treatment. All measurement leaves expanded after the beginning of the treatments. Pre-dawn (0600-0800 HR) leaf water potential $\left(\psi_{\mathrm{w}}\right)$ was measured using a Scholander-type pressure chamber (PMS instruments, Corvallis, Ore.; Scholander et al., 1965). Following $\psi_{\mathrm{w}}$, leaves were immediately wrapped in aluminum foil, frozen by immersing in liquid nitrogen and stored at $-18^{\circ} \mathrm{C}$. Leaf osmotic potential $\left(\psi_{\pi}\right)$ was measured on sap pressed from the thawed tissue at $25 \pm 1{ }^{\circ} \mathrm{C}$ with a vapor pressure osmometer (model 5100B, Wescor, Logan, Utah). Turgor potential $\left(\psi_{\mathrm{p}}\right)$ was calculated as the difference between the $\psi_{\pi}$ and $\psi_{\mathrm{w}^{*}}$

Net assimilation of $\mathrm{CO}_{2}\left(\mathrm{~A}_{\mathrm{CO} 2}\right)$, stomatal conductance $\left(\mathrm{g}_{\mathrm{s}}\right)$, leaf transpiration $\left(\mathrm{E}_{\mathrm{lf}}\right)$, intercellular $\mathrm{CO}_{2}$ concentration $\left(\mathrm{C}_{\mathrm{i}}\right)$, ambient $\mathrm{CO}_{2}$ concentration $\left(\mathrm{C}_{\mathrm{a}}\right)$, and water-use efficiency $\left(\mathrm{WUE}=\mathrm{A}_{\mathrm{CO} 2} / \mathrm{E}_{\mathrm{lf}}\right)$ were determined with a portable photosynthesis system(LI-6200; LI-COR) using a 0.25-L cuvette. The LICOR-6200 was equipped with an external light source (model QB1205LI-670; Quantum Devices, Barneveld, Wis.) to maintain a constant $P A R$ of $\geq 800$ $\mu \mathrm{mol} \cdot \mathrm{m}^{-2} \cdot \mathrm{s}^{-1}$ during measurements. This $P A R$ is sufficient for sunacclimated citrus leaves to achieve maximum $\mathrm{A}_{\mathrm{CO} 2}$ (Syvertsen,
1984). All measurements were made in the morning from 0800 to $1000 \mathrm{HR}$ to avoid high temperature and low humidity in the afternoon. During all measurements, leaf temperature was $32 \pm$ $2{ }^{\circ} \mathrm{C}$ and leaf-to-air vapor pressure difference (VPD) was $2.4 \pm$ $0.4 \mathrm{kPa}$ within the cuvette. Measurements were made on a single leaf on each of the eight replicate plants in each treatment.

ChLOROPHYLl A FLUORESCENCE MEASUREMENTS. Chlorophyll $a$ fluorescence characteristics were measured with a pulse modulated fluorometer (model OS1-Fl; Opti-Sciences, Tyngsboro, Mass.) on similar leaves that were used for gas exchange measurements. Fluorescence measurements were made between 0900 and 1000 HR using a single leaf from each of the eight replicate plants per treatment under ambient light and also after 15 min of dark acclimation under leaf clips (FL-DC; Opti-Sciences). The parameters of maximum quantum efficiency $(\mathrm{Fv} / \mathrm{Fm})$ of photosystem II were calculated as $\mathrm{Fv} / \mathrm{Fm}=(\mathrm{Fm}-\mathrm{Fo}) / \mathrm{Fm}$; where Fm and Fo were maximum and minimum fluorescence of dark acclimated leaves, respectively (Jifon and Syvertsen, 2003; Maxwell and Johnson, 2000). Effective quantum yield $(Y)$ was measured as $Y=\left(\mathrm{F}^{\prime}{ }_{\mathrm{M}}\right.$ $\left.-\mathrm{F}^{\prime}\right) / \mathrm{F}^{\prime}{ }_{\mathrm{M}}$ where $\mathrm{F}^{\prime}{ }_{\mathrm{M}}$ and $\mathrm{F}^{\prime}$ were the maximum and steady-state fluorescence yield in the light, respectively.

Chlorophyll analysis. After gas exchange and fluorescence measurements, two leaf disks $\left(0.45 \mathrm{~cm}^{2}\right.$ each $)$ were sampled from the same leaves avoiding major veins. Chlorophyll was eluted from the discs by submerging them in $2 \mathrm{~mL}$ of $N, N$-Dimethylformamide in the dark for at least $72 \mathrm{~h}$. Absorbances of extract solutions were read at 647 and $664 \mathrm{~nm}$ with a Shimadzu UV-vis spectrophotometer (model UV2401PC; Shimadzu, Columbia, Md.) and used to calculate leaf chlorophyll concentrations using equations in Inskeep and Bloom (1985).

Plant transpiration and leaf area. Two days before ending of the experiment, whole plant transpiration $\left(\mathrm{E}_{\mathrm{wp}}\right)$ was measured by weight loss from each pot during two 6- to 7-h daytime periods on two selected clear days. Daily weight loss per pot was averaged for the $2 \mathrm{~d}$. Pots were covered with plastic bags sealed at the base of the stem to stop soil evaporation. Total leaf area per plant was measured (LI-3000; LI-COR) $2 \mathrm{~d}$ later and used to express $\mathrm{E}_{\mathrm{wp}}$ in units of $\mathrm{mmol} \cdot \mathrm{m}^{-2} \cdot \mathrm{s}^{-1}$.

GROWTH AND LEAF NUTRIENT CONCENTRATION. Eight weeks after initiating the salinity and $\mathrm{CO}_{2}$ treatments, plants were harvested and separated into leaves, stems, and roots. Tissues were briefly rinsed with deionised water, oven-dried at $60^{\circ} \mathrm{C}$ for at least $48 \mathrm{~h}$, weighed and ground to a fine powder. Leaf and root tissue samples were extracted with $0.1 \mathrm{~N}$ solution of nitric acid and $10 \%$ acetic acid. Tissue chloride concentration was measured using a silver ion titration chlorodimeter (HBI Chlorodimeter; Haake Buchler, Saddle Brook, N.J.). Tissue N, Na, and $\mathrm{Ca}^{+2}$ concentrations were determined by a commercial laboratory (Waters Agricultural Lab, Camilla, Ga.).

STATISTICAL ANALYSIS. Data were subjected to analysis of variance using two rootstocks $\times$ two $\mathrm{CO}_{2}$ levels $\times$ two salinity levels as main effects and eight replicate plants per treatment. Treatment means were compared using Duncan's multiple range test at $P<$ 0.05 using SPSS statistical package (SPSS, Chicago).

\section{Results}

GrowTH. Leaf dry weight and total plant dry weight (TPDW) of Cleopatra (Cleo) were higher than that of Carrizo (Carr; Table 1). After 8 weeks in elevated $\mathrm{CO}_{2}$, TPDW was increased by increasing leaf dry weight and LDW/a of both genotypes. Salinity reduced leaf dry weights and TPDW of both genotypes. Despite 
Table 1. Effects of $\mathrm{CO}_{2}$ concentration and soil $\mathrm{NaCl}(0$ or $50 \mathrm{~mm} \mathrm{NaCl})$ on mean $(\mathrm{n}=8)$ dry weight of leaves, roots, total plant dry weight (TPDW), leaf dry weight per area (LDW/a), and shoot-to-root ratio (S/R) of Cleopatra mandarin and Carrizo citrange seedlings.

\begin{tabular}{|c|c|c|c|c|c|c|c|}
\hline Rootstock & $\begin{array}{c}\mathrm{CO}_{2} \\
\left(\mu \mathrm{L} \cdot \mathrm{L}^{-1}\right)\end{array}$ & Salt & $\begin{array}{c}\text { Dry wt } \\
\text { leaves }(\mathrm{g})\end{array}$ & $\begin{array}{l}\text { Dry wt } \\
\text { root }(\mathrm{g})\end{array}$ & $\begin{array}{l}\text { TPDW } \\
\text { (g) }\end{array}$ & $\begin{array}{c}\mathrm{LDW} / \mathrm{a} \\
\left(\mathrm{g} \cdot \mathrm{m}^{-2}\right)\end{array}$ & $\mathrm{S} / \mathrm{R}$ \\
\hline \multirow[t]{4}{*}{ Cleopatra } & 360 & No salt & $4.22 \mathrm{~b}^{\mathrm{z}}$ & $2.87 \mathrm{abc}$ & $11.68 \mathrm{~b}$ & $93.3 \mathrm{bc}$ & $3.33 \mathrm{ab}$ \\
\hline & & Salt & $2.80 \mathrm{c}$ & $2.19 \mathrm{c}$ & $8.28 \mathrm{~cd}$ & $87.7 \mathrm{c}$ & $2.78 \mathrm{bc}$ \\
\hline & 700 & No salt & $6.12 \mathrm{a}$ & $3.62 \mathrm{a}$ & $16.33 \mathrm{a}$ & $105.7 \mathrm{a}$ & $3.62 \mathrm{a}$ \\
\hline & & Salt & $3.57 \mathrm{~b}$ & $2.87 \mathrm{abc}$ & $10.54 \mathrm{bc}$ & $93.4 \mathrm{bc}$ & $2.75 \mathrm{bc}$ \\
\hline \multirow[t]{5}{*}{ Carrizo } & 360 & No salt & $1.66 \mathrm{~d}$ & $3.22 \mathrm{ab}$ & $9.01 \mathrm{c}$ & $80.8 \mathrm{~d}$ & $1.80 \mathrm{~d}$ \\
\hline & & Salt & $0.92 \mathrm{e}$ & $2.42 \mathrm{bc}$ & $5.99 \mathrm{~d}$ & $77.3 \mathrm{~d}$ & $1.74 \mathrm{~d}$ \\
\hline & 700 & No salt & $2.38 \mathrm{c}$ & $3.83 \mathrm{a}$ & $12.90 \mathrm{~b}$ & $91.6 \mathrm{bc}$ & $2.44 \mathrm{c}$ \\
\hline & & Salt & $1.66 \mathrm{~d}$ & $2.61 \mathrm{bc}$ & $8.94 \mathrm{c}$ & $95.4 \mathrm{~b}$ & $2.45 \mathrm{c}$ \\
\hline & & & \multicolumn{2}{|c|}{ Analysis of variance } & & & \\
\hline \multicolumn{2}{|l|}{ Rootstock } & & $* * *$ & NS & $* * *$ & $* * *$ & $* * *$ \\
\hline \multicolumn{2}{|l|}{$\mathrm{CO}_{2}$} & & $* * *$ & $*$ & $* * *$ & $* * *$ & $* *$ \\
\hline \multicolumn{2}{|l|}{ Salinity } & & $* * *$ & $* * *$ & $* * *$ & $*$ & $*$ \\
\hline \multicolumn{2}{|c|}{ Rootstock $\times \mathrm{CO}_{2}$} & & NS & NS & NS & NS & NS \\
\hline \multicolumn{2}{|c|}{$\mathrm{CO}_{2} \times$ salinity } & & NS & NS & NS & NS & NS \\
\hline \multicolumn{2}{|c|}{ Rootstock $\times \mathrm{CO}_{2} \times$ salinity } & & NS & NS & NS & $*$ & NS \\
\hline
\end{tabular}

${ }^{\mathrm{z} W i t h i n}$ each column, means followed by the same letters are not significantly different at $5 \%$.

NS, *,**,***Nonsignificant differences or significant differences at $P<0.05,0.01$, or 0.001 , respectively.

the salinity reduced leaf dry weights, salinized plants of both genotypes grown at $\mathrm{eCO}_{2}$ had leaf dry weighs similar to those of nonsalinized control plants at $\mathrm{aCO}_{2}$. The relative increase in leaf dry weight in $\mathrm{eCO}_{2}$ was significantly greater in salinized Carr (from 0.92 to $1.66 \mathrm{~g}=80 \%$ ) than in nonsalinized Carr (1.66 to $2.38 \mathrm{~g}=43 \%)$. The analogous $\mathrm{eCO}_{2}$-induced increases in Cleo seedlings varied from $27 \%$ to $45 \%$ and did not differ between salt treatments. Nonsalinized plants at $\mathrm{eCO}_{2}$ had higher root dry weight than salinized plants at $\mathrm{aCO}_{2}$ for both genotypes. Root dry weight was only reduced by salinity at $\mathrm{eCO}_{2}$ in Carr. The shoot-to-root dry weight ratio $(\mathrm{S} / \mathrm{R})$ of Carr was significantly higher when grown at $\mathrm{eCO}_{2}$ than at $\mathrm{aCO}_{2}$ for both salinity treatments but not in Cleo.

Leaf $\mathrm{CL}^{-}$and $\mathrm{Na}^{+}$CONCENTRation. Salinity increased the concentrations of $\mathrm{Cl}^{-}$and $\mathrm{Na}^{+}$in leaves and roots of both genotypes (Fig. 1). The $\mathrm{Cl}^{-}$concentration in leaves and roots was higher for Carr than for Cleo regardless of $\mathrm{CO}_{2}$ level. The concentration of $\mathrm{Na}^{+}$was higher in leaves of Cleo than in Carr but roots of both genotypes had similar $\mathrm{Na}^{+}$concentrations. Elevated $\mathrm{CO}_{2}$ decreased $\mathrm{Cl}^{-}$and $\mathrm{Na}^{+}$concentrations in leaves of salinized Carr and also decreased both $\mathrm{Cl}^{-}$and $\mathrm{Na}^{+}$in roots of salinized Cleo. In salinized seedlings of both genotypes, $\mathrm{Cl}^{-}$and $\mathrm{Na}^{+}$concentration changes in response to $\mathrm{eCO}_{2}$ in leaves $v s$. roots were generally in opposite directions. Visible $\mathrm{Cl}^{-}$toxicity symptoms such as leaf tip burn were observed on a few leaves of both Cleo and Carr but there was no leaf abscission during the period of this study.

Leaf $\mathrm{CA}^{+2}$ and total-N Concentration. Leaf $\mathrm{Ca}^{+2}$ and $\mathrm{N}$ concentrations were higher in Carr than in Cleo (Fig. 2). Elevated $\mathrm{CO}_{2}$ significantly decreased $\mathrm{Ca}^{2+}$ and $\mathrm{N}$ and in the nonsalinized Cleo leaves. Salinity decreased leaf $\mathrm{Ca}^{+2}$ and increased leaf N in Cleo grown at $\mathrm{aCO}_{2}$. However, salinity did not affect leaf $\mathrm{N}$ and $\mathrm{Ca}^{2+}$ at $\mathrm{eCO}_{2}$. Salinity decreased leaf $\mathrm{Ca}^{+2}$ in Carr at $\mathrm{eCO}_{2}$, but there were no significant effects on leaf $\mathrm{N}$ attributable to salinity or $\mathrm{CO}_{2}$ treatment. Salinity decreased root $\mathrm{Ca}^{2+}$ and increased root $\mathrm{N}$ in both genotypes regardless of $\mathrm{CO}_{2}$ level. Root $\mathrm{Ca}^{+2}$ and $\mathrm{N}$ concentrations were not affected by $\mathrm{eCO}_{2}$.

LEAF WATER RELATIONS. Elevated $\mathrm{CO}_{2}$ did not affect $\psi_{\mathrm{w}}, \psi_{\pi}$, and $\psi_{\mathrm{p}}$ in Cleo leaves regardless of salinity treatment (Table 2).
In nonsalinized Carr leaves, however, $\mathrm{eCO}_{2}$ reduced the $\psi_{\mathrm{w}}$ and $\psi_{\mathrm{p}}$, and increased $\psi_{\pi}$ with respect to $\mathrm{aCO}_{2}$. Salinity decreased $\psi_{\mathrm{w}}$ and $\psi_{\pi}$ such that $\psi_{\mathrm{p}}$ was increased in both Cleo and Carr leaves. In salinized Carr, $\psi_{\mathrm{w}}$ was lower for plants grown at $\mathrm{eCO}_{2}$ than at $\mathrm{aCO}_{2}$ but $\psi_{\mathrm{p}}$ was not reduced significantly.

LEAF GAS EXCHANGE. Net $\mathrm{A}_{\mathrm{CO} 2}$ and $\mathrm{g}_{\mathrm{s}}$ of Carr leaves was generally greater than that of Cleo regardless of treatment (Table 3 ). Under nonsaline conditions, $\mathrm{eCO}_{2}$ increased $\mathrm{A}_{\mathrm{CO} 2}$ and WUE but decreased $g_{s}$ in both genotypes. Salinity reduced net gas exchange in both genotypes. Salinized Carr and Cleo plants grown at $\mathrm{eCO}_{2}$ had higher or similar values of $\mathrm{A}_{\mathrm{CO} 2}$ than their respective nonsalinized plants grown at $\mathrm{aCO}_{2}$. There was a significant interaction effect between $\mathrm{eCO}_{2}$ and salinity on $\mathrm{g}_{\mathrm{s}}$ in both genotypes as stomatal conductance was reduced by salinity at $\mathrm{aCO}_{2}$, but the lowered $\mathrm{g}_{\mathrm{s}}$ at $\mathrm{eCO}_{2}$ were unaffected by salinity. Overall, salinity decreased WUE regardless of $\mathrm{CO}_{2}$ treatment. There was also a significant $\mathrm{CO}_{2} \times$ salinity interaction effect on $\mathrm{C}_{\mathrm{i}} / \mathrm{C}_{\mathrm{a}}$ in Cleo leaves as salinity decreased $\mathrm{C}_{\mathrm{i}} / \mathrm{C}_{\mathrm{a}}$ at $\mathrm{aCO}_{2}$ but increased $\mathrm{C}_{\mathrm{i}} / \mathrm{C}_{\mathrm{a}}$ at $\mathrm{eCO}_{2}$. Although trends in $\mathrm{C}_{\mathrm{i}} / \mathrm{C}_{\mathrm{a}}$ were similar in Carr, there were no significant effects attributable to salinity or $\mathrm{CO}_{2}$ treatments.

CHLOROPHYLL FLUORESCENCE AND LEAF CHLOROPHYLL CONTENT. $\mathrm{Fv} / \mathrm{Fm}, \mathrm{Y}$, and leaf chlorophyll concentration were higher in Carr than in Cleo leaves (Table 4). There were no significant differences in $\mathrm{Fv} / \mathrm{Fm}$ attributed to $\mathrm{eCO}_{2}$ or salinity. Quantum yields ( $\mathrm{Y}$ ) generally increased at $\mathrm{CO}_{2}$, but differences were only significant in nonsalinized Cleo. There was a significant $\mathrm{CO}_{2}$ and salinity interaction effect on total chlorophyll concentration as salinity decreased total chlorophyll at $\mathrm{eCO}_{2}$ but had no effect at $\mathrm{aCO}_{2}$.

Transpiration. Carr leaves had a higher $\mathrm{E}_{\mathrm{wp}}$ than Cleo leaves (Fig. 3). Salinity and $\mathrm{eCO}_{2}$ reduced $\mathrm{E}_{\mathrm{wp}}$ in both genotypes except in Carr plants at $\mathrm{eCO}_{2}$ where the already lowered $\mathrm{E}_{\mathrm{wp}}$ was not decreased additionally by the salt treatment.

\section{Discussion}

Although salt-stress generally reduces nutrient uptake, leaf growth and the rate of $\mathrm{A}_{\mathrm{CO} 2}$, the $\mathrm{A}_{\mathrm{CO} 2}$ of salinized plants grown at $\mathrm{eCO}_{2}$ was either equal to or higher than that of nonsalinized 


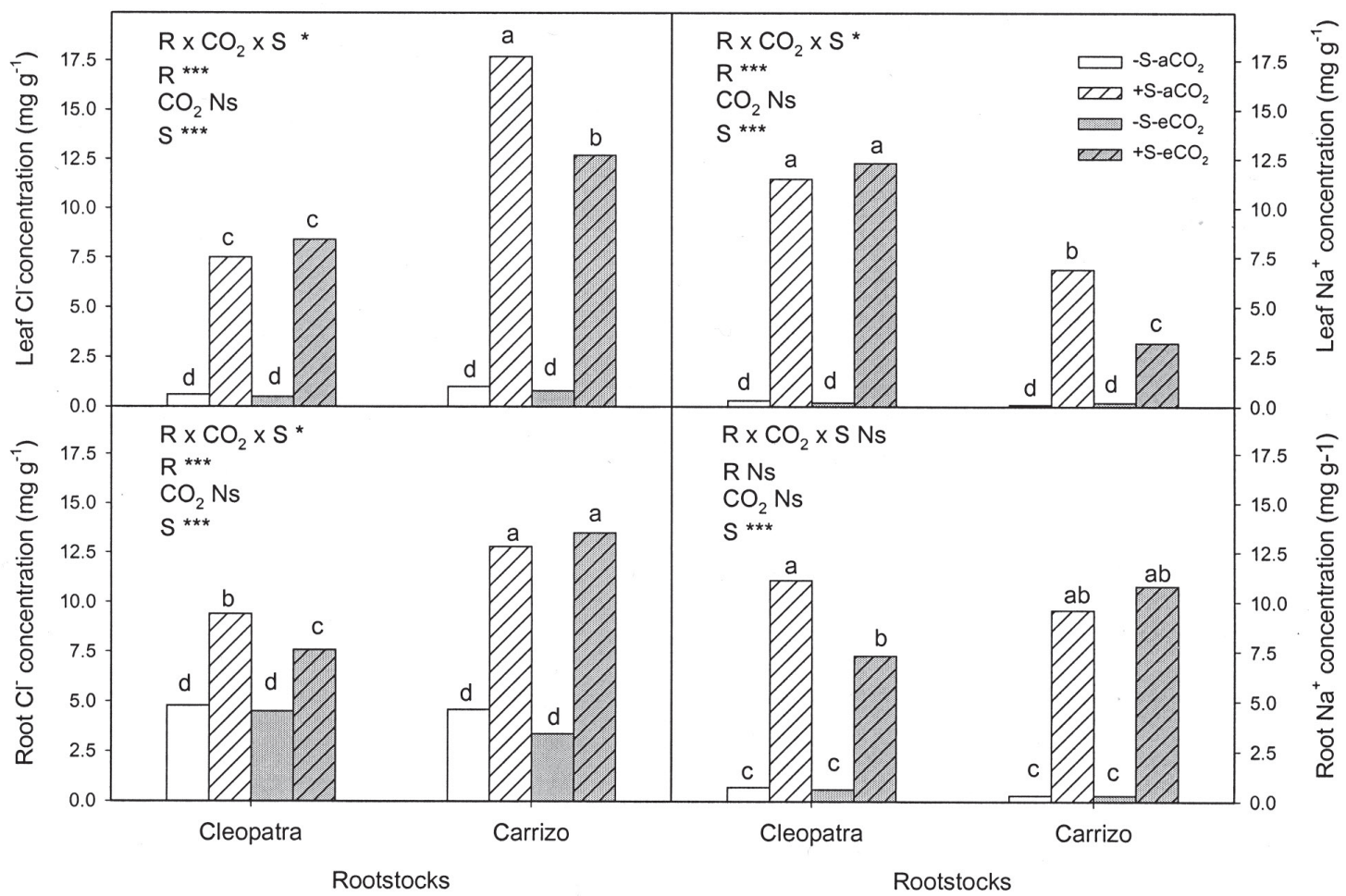

Fig. 1. Effects of soil $\mathrm{NaCl}(-\mathrm{S}=0 \mathrm{mM},+\mathrm{S}=50 \mathrm{~mm})$ and growing at ambient $\mathrm{CO}_{2}\left(\mathrm{aCO}_{2}=360 \mu \mathrm{L}^{-} \mathrm{L}^{-1}\right)$ or at elevated $\mathrm{CO}_{2}\left(\mathrm{eCO} \mathrm{CO}_{2}=700 \mu \mathrm{L} \cdot \mathrm{L}^{-1}\right)$ on mean $(\mathrm{n}=8)$ $\mathrm{Cl}-$ and $\mathrm{Na}^{+}$concentration (mg.g-1 dry weight) in leaf and root tissue of Cleopatra mandarin and Carrizo citrange seedlings. Different letters within each figure indicate significant differences at $P<0.05$ (Duncan's test). NS, ${ }^{*}{ }^{* *}, * * *$ Nonsignificant differences or significant differences at $P<0.05,0.01$, or 0.001 , respectively, for the three-way interaction of two rootstocks $\times$ two salt treatments $\times$ two $\mathrm{CO}_{2}$ levels $(\mathrm{R} \times \mathrm{C} \times \mathrm{S})$ and for the rootstock effect.

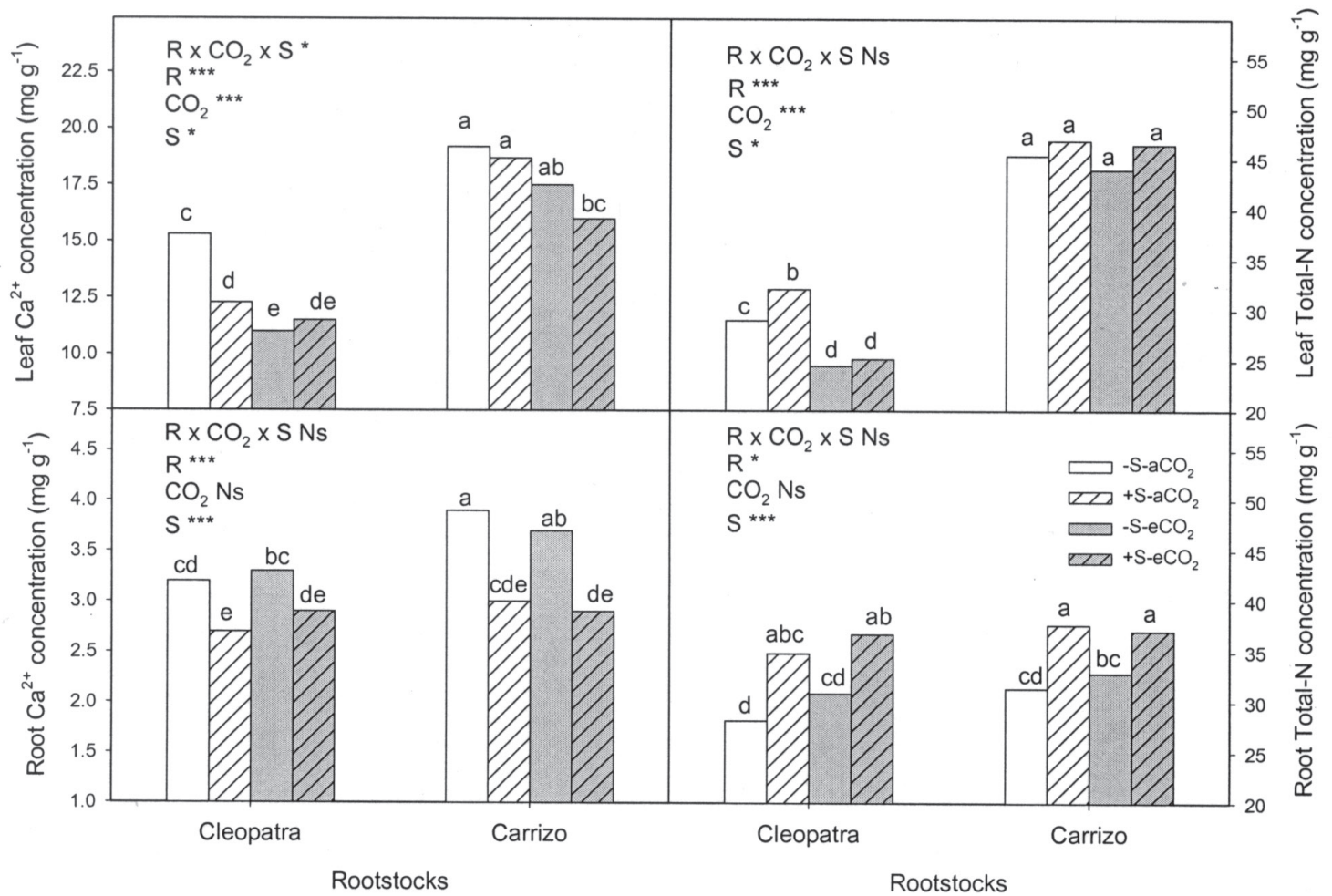

Fig. 2. Effects of soil $\mathrm{NaCl}(-\mathrm{S}=0 \mathrm{~mm},+\mathrm{S}=50 \mathrm{~mm})$ and growing at ambient $\mathrm{CO}_{2}\left(\mathrm{aCO}_{2}=360 \mu \mathrm{L} \cdot \mathrm{L}^{-1}\right)$ or at elevated $\mathrm{CO}_{2}\left(\mathrm{eCO}_{2}=700 \mu \mathrm{L} \cdot \mathrm{L}^{-1}\right)$ on mean $(\mathrm{n}=8) \mathrm{Ca}{ }^{2+}$ and $\mathrm{N}$ concentration ( $\mathrm{mg} \cdot \mathrm{g}^{-1}$ dry weight) in leaf and root tissue of Cleopatra mandarin and Carrizo citrange seedlings. Different letters within each figure indicate significant differences at $P<0.05$ (Duncan's test). Ns, ${ }^{*}, * * * * *$ Nonsignificant differences or significant differences at $P<0.05,0.01$, or 0.001 , respectively, for the three-way interaction of two rootstocks $\times$ two salt treatments $\times$ two $\mathrm{CO}_{2}$ levels $(\mathrm{R} \times \mathrm{C} \times \mathrm{S})$ and for the rootstock effect. 
Table 2. Effects of $\mathrm{CO}_{2}$ concentration and $\mathrm{NaCl}(0$ or $50 \mathrm{~mm} \mathrm{NaCl})$ on mean $(\mathrm{n}=8)$ leaf water potential $\left(\psi_{\mathrm{w}}\right)$, leaf osmotic potential $\left(\psi_{\pi}\right)$, and leaf turgor potential $\left(\psi_{\mathrm{p}}\right)$ of Cleopatra mandarin and Carrizo citrange leaves.

\begin{tabular}{|c|c|c|c|c|c|}
\hline Rootstock & $\begin{array}{c}\mathrm{CO}_{2} \\
\left(\mu \mathrm{L} \cdot \mathrm{L}^{-1}\right)\end{array}$ & Salt & $\psi_{\mathrm{w}}(\mathrm{MPa})$ & $\psi_{\pi}(\mathrm{Mpa})$ & $\psi_{\mathrm{p}}(\mathrm{Mpa})$ \\
\hline \multirow[t]{4}{*}{ Cleopatra } & 360 & No salt & $-0.34 \mathrm{a}^{\mathrm{z}}$ & $-2.54 \mathrm{ab}$ & $2.19 \mathrm{de}$ \\
\hline & & Salt & $-0.46 \mathrm{bc}$ & $-3.00 \mathrm{c}$ & $2.55 \mathrm{ab}$ \\
\hline & 700 & No salt & $-0.35 \mathrm{a}$ & $-2.34 \mathrm{a}$ & 1.99 ef \\
\hline & & Salt & $-0.52 \mathrm{c}$ & $-3.23 \mathrm{c}$ & $2.71 \mathrm{a}$ \\
\hline \multirow[t]{4}{*}{ Carrizo } & 360 & No salt & $-0.42 \mathrm{ab}$ & $-2.67 b$ & $2.25 \mathrm{~cd}$ \\
\hline & & Salt & $-0.69 \mathrm{~d}$ & $-3.15 \mathrm{c}$ & $2.47 \mathrm{abc}$ \\
\hline & 700 & No salt & $-0.51 \mathrm{c}$ & $-2.32 \mathrm{a}$ & $1.81 \mathrm{f}$ \\
\hline & & Salt & $-0.91 \mathrm{e}$ & $-3.21 \mathrm{c}$ & $2.30 \mathrm{bcd}$ \\
\hline \multicolumn{6}{|c|}{ Analysis of variance } \\
\hline \multicolumn{2}{|l|}{ Rootstock } & & $* * *$ & NS & * \\
\hline \multicolumn{2}{|l|}{$\mathrm{CO}_{2}$} & & $* * *$ & NS & * \\
\hline \multicolumn{2}{|l|}{ Salinity } & & $* * *$ & $* * *$ & $* * *$ \\
\hline \multicolumn{2}{|c|}{ Rootstock $\times \mathrm{CO}_{2}$} & & $* *$ & NS & * \\
\hline \multicolumn{2}{|c|}{ Rootstock $\times$ salinity } & & $* * *$ & NS & NS \\
\hline \multicolumn{2}{|c|}{$\mathrm{CO}_{2} \times$ salinity } & & $*$ & $* * *$ & * \\
\hline \multicolumn{2}{|c|}{ Rootstock $\times \mathrm{CO}_{2} \times$ salinity } & & NS & NS & NS \\
\hline
\end{tabular}

${ }^{2}$ Within each column, means followed by the same letters are not significantly different at $5 \%$. NS, *,******Nonsignificant differences or significant differences at $P<0.05,0.01$, or 0.001 , respectively.

Table 3. Effects of $\mathrm{CO}_{2}$ concentration and soil $\mathrm{NaCl}(0$ or $50 \mathrm{~mm} \mathrm{NaCl})$ on mean $(\mathrm{n}=8)$ net $\mathrm{CO}_{2}$ assimilation rate $\left(\mathrm{A}_{\mathrm{CO} 2}\right)$, stomatal conductance $\left(\mathrm{g}_{\mathrm{s}}\right)$, water-use efficiency (WUE), and $\mathrm{CO}_{2}$ internal/external $[\mathrm{Ci} / \mathrm{Ca}$ (dimensionless)] of Cleopatra mandarin and Carrizo citrange leaves.

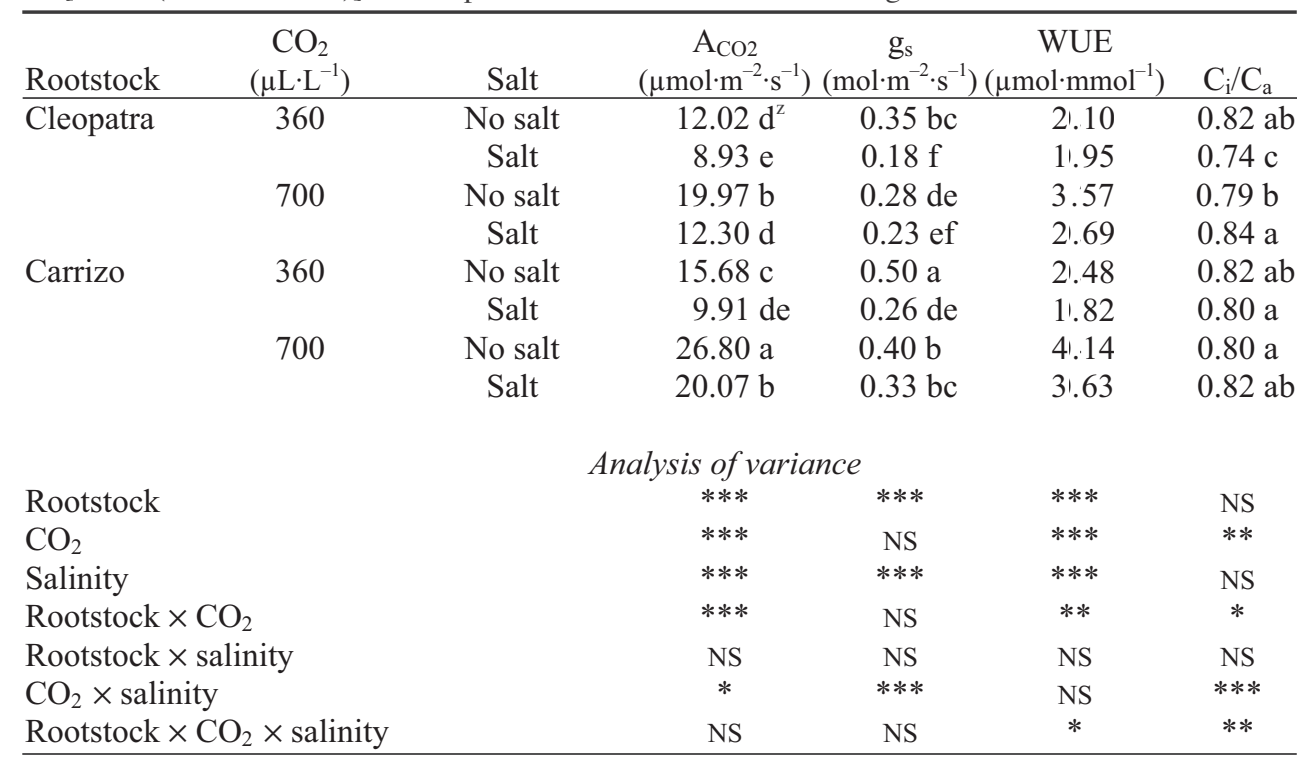

zWithin each column, means followed by the same letters are not significantly different at $5 \%$. NS, $*, *, * * *$ Nonsignificant differences or significant differences at $P<0.05,0.01$, or 0.001 , respectively.

plants at $\mathrm{aCO}_{2}$. In addition, salinized plants at $\mathrm{eCO}_{2}$ had similar leaf growth and TPDW as nonsalinized plants at $\mathrm{aCO}_{2}$. Thus, $\mathrm{eCO}_{2}$ mitigated both the $\mathrm{A}_{\mathrm{CO} 2}$ and growth reduction response to salinity in both Cleo and Carr seedlings. In Cleo, the increase of leaf growth in response to $\mathrm{eCO}_{2}$ was similar regardless of salt treatment whereas in Carr, the leaf growth increase was higher for the salinized than in nonsalinized seedlings (Table 1). Elevated $\mathrm{CO}_{2}$ also reduced leaf $\mathrm{Cl}^{-}$and $\mathrm{Na}^{+}$concentration in Carr leaves allowing photosynthetic rate to double at $\mathrm{eCO}_{2}$ compared to salinized plants at $\mathrm{aCO}_{2}$. Thus, based on leaf growth, net gas exchange and salt ion concentration, $\mathrm{eCO}_{2}$ increased salinity tolerance in the relative salt sensitive Carr which supports our original hypothesis. In contrast, leaf $\mathrm{Cl}^{-}$and $\mathrm{Na}^{+}$concentrations in the more salt tolerant Cleo were not affected by $\mathrm{eCO}_{2}$ and $\mathrm{eCO}_{2}$ increased $\mathrm{A}_{\mathrm{CO} 2}$ by only $\approx 1.3$ fold.

Elevated $\mathrm{CO}_{2}$ apparently increased the sensitivity of leaf chlorophyll to salinity but this was not related to the measured fluorescence parameters or $\mathrm{ACO}_{2}$ where there were no significant interacting effects between $\mathrm{CO}_{2}$ and salinity. Salinity stress tended to have similar effects on leaf water relations, fluorescence parameters, and net gas exchange characteristics regardless of the $\mathrm{CO}_{2}$ level. The decrease in $\mathrm{ACO}_{2}$ by salinity was probably due to $\mathrm{Na}^{+}$and/or $\mathrm{Cl}^{-}$ion accumulation as changes in leaf turgor were not responsible for the decline in $\mathrm{A}_{\mathrm{CO} 2}$ assimilation (also 
Table 4. Effects of $\mathrm{CO}_{2}$ concentration and soil $\mathrm{NaCl}(0$ or $50 \mathrm{~mm} \mathrm{NaCl})$ on mean $(\mathrm{n}=8)$ fluorescence of maximum quantum yield of dark acclimated leaves ( Fv/Fm), effective quantum yield of light acclimated leaves $(Y)$ and total chlorophyll concentration $\left(\mathrm{g} \cdot \mathrm{cm}^{-2}\right)$ of Cleopatra mandarin and Carrizo citrange leaves.

\begin{tabular}{|c|c|c|c|c|c|}
\hline Rootstock & $\begin{array}{c}\mathrm{CO}_{2} \\
\left(\mu \mathrm{L} \cdot \mathrm{L}^{-1}\right)\end{array}$ & Salt & $\mathrm{Fv} / \mathrm{Fm}$ & $Y$ & $\begin{array}{c}\text { Total } \\
\text { chlorophyll }\end{array}$ \\
\hline \multirow[t]{4}{*}{ Cleopatra } & 360 & No salt & $0.713 \mathrm{bcd}^{\mathrm{z}}$ & $0.38 \mathrm{c}$ & $0.307 \mathrm{~d}$ \\
\hline & & Salt & $0.705 \mathrm{bcd}$ & $0.42 \mathrm{c}$ & $0.315 \mathrm{~d}$ \\
\hline & 700 & No salt & $0.674 \mathrm{~d}$ & $0.51 \mathrm{ab}$ & $0.425 \mathrm{c}$ \\
\hline & & Salt & $0.693 \mathrm{~cd}$ & $0.44 \mathrm{bc}$ & $0.274 \mathrm{~d}$ \\
\hline \multirow[t]{5}{*}{ Carrizo } & 360 & No salt & $0.783 \mathrm{a}$ & $0.56 \mathrm{a}$ & $0.513 \mathrm{~b}$ \\
\hline & & Salt & $0.748 \mathrm{abc}$ & $0.51 \mathrm{ab}$ & $0.475 \mathrm{bc}$ \\
\hline & 700 & No salt & $0.775 \mathrm{a}$ & $0.58 \mathrm{a}$ & $0.585 \mathrm{a}$ \\
\hline & & Salt & $0.760 \mathrm{ab}$ & $0.53 \mathrm{a}$ & $0.485 \mathrm{~b}$ \\
\hline & & Analysi & ance & & \\
\hline \multicolumn{2}{|l|}{ Rootstock } & & $* * *$ & $* * *$ & $* * *$ \\
\hline \multicolumn{2}{|l|}{$\mathrm{CO}_{2}$} & & NS & $*$ & $* *$ \\
\hline \multicolumn{2}{|l|}{ Salinity } & & NS & NS & $* * *$ \\
\hline \multicolumn{2}{|c|}{ Rootstock $\times \mathrm{CO}_{2}$} & & NS & NS & NS \\
\hline \multicolumn{2}{|c|}{ Rootstock $\times$ salinity } & & NS & NS & NS \\
\hline \multicolumn{2}{|c|}{$\mathrm{CO}_{2} \times$ salinity } & & NS & NS & $* * *$ \\
\hline \multicolumn{2}{|c|}{ Rootstock $\times \mathrm{CO}_{2} \times$ salinity } & & NS & NS & NS \\
\hline
\end{tabular}

${ }^{z}$ Within each column, means followed by the same letters are not significantly different at $5 \%$.

NS, ***,***NNonsignificant differences or significant differences at $P<0.05,0.01$, or 0.001 , respectively.

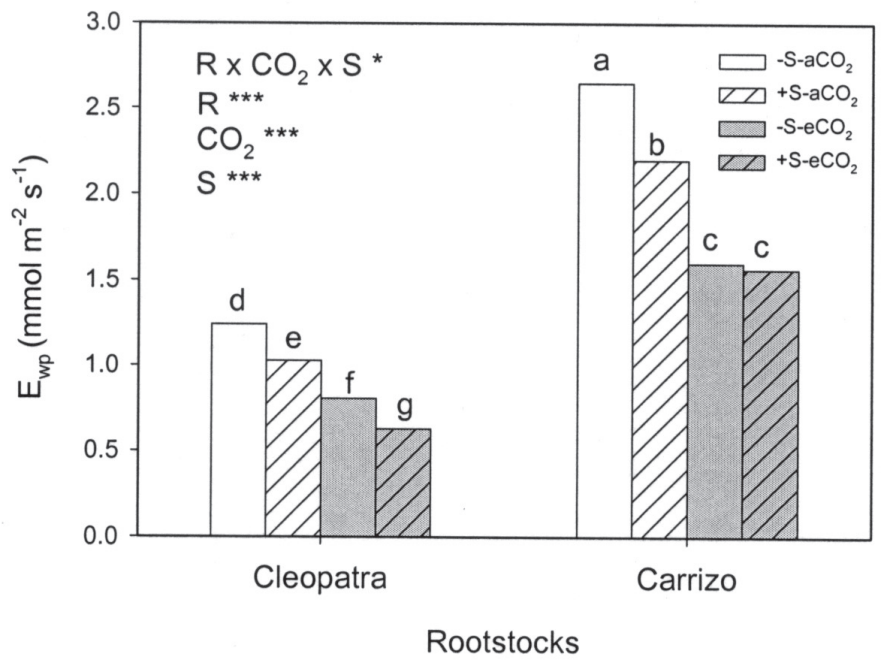

Fig. 3. Effects of soil $\mathrm{NaCl}(-\mathrm{S}=0 \mathrm{~mm},+\mathrm{S}=50 \mathrm{~mm})$ and growing at ambient $\mathrm{CO}_{2}\left(\mathrm{aCO}_{2}=360 \mu \mathrm{L} \cdot \mathrm{L}^{-1}\right)$ or at elevated $\mathrm{CO}_{2}\left(\mathrm{eCO}_{2}=700 \mu \mathrm{L} \cdot \mathrm{L}^{-1}\right)$ on mean $(\mathrm{n}=$ 8 ) whole plant transpiration $\left(\mathrm{E}_{\mathrm{wp}}\right)$ of Cleopatra mandarin and Carrizo citrange seedlings. Different letters within each figure indicate significant differences at $P<0.05$ (Duncan's test). Ns, $*, * *, * * *$ Nonsignificant differences or significant differences at $P<0.05,0.01$ or 0.001 , respectively, for the three-way interaction of two rootstocks $\times$ two salt treatments $\times$ two $\mathrm{CO}_{2}$ levels $(\mathrm{R} \times \mathrm{C} \times \mathrm{S})$ and for the rootstock effect.

see Bañuls and Primo-Millo, 1992). The absence of a significant decrease in fluorescence parameters ( $\mathrm{Fv} / \mathrm{Fm}$ and $Y$ ) also negated the possibility of photoinhibition as a cause of reduced photosynthetic rates. Lloyd et al. (1987b) also observed an insensitivity of fluorescence to high foliar salt levels in citrus leaves when turgor was maintained.

Although $\mathrm{A}_{\mathrm{CO} 2}$ and $\mathrm{g}_{\mathrm{s}}$ were decreased by salinity in both genotypes at $\mathrm{aCO}_{2}, \mathrm{C}_{\mathrm{i}} / \mathrm{C}_{\mathrm{a}}$ also decreased in salinized $\mathrm{Cleo}$ at $\mathrm{aCO}_{2}$ but not in Carr. Thus, $\mathrm{g}_{\mathrm{s}}$ could have limited $\mathrm{A}_{\mathrm{CO} 2}$ (Farquhar and Sharkey, 1982) in salinized Cleo leaves where low $g_{s}$ may have been related to high leaf $\mathrm{Na}^{+}$. In salinized Carr leaves with higher $\mathrm{g}_{\mathrm{s}}$ and leaf $\mathrm{Cl}^{-}$than Cleo leaves, however, $\mathrm{C}_{\mathrm{i}} / \mathrm{C}_{\mathrm{a}}$ did not decrease with decreasing $\mathrm{A}_{\mathrm{CO} 2}$. Thus, $\mathrm{g}_{\mathrm{s}}$ was not as important in limiting $\mathrm{A}_{\mathrm{CO} 2}$ as internal limitations (biochemical) in the mesophyll of salinized Carr. At eCO $\mathrm{C}_{2}, \mathrm{~A}_{\mathrm{CO} 2}$ and $\mathrm{g}_{\mathrm{s}}$ both decreased as result of salt stress in both genotypes, but the $\mathrm{g}_{\mathrm{s}}$ limitation was removed by $\mathrm{eCO}_{2}$ and $\mathrm{C}_{\mathrm{i}} / \mathrm{Ca}$ increased. This underscored the fact that at $\mathrm{eCO}_{2}$, internal limitations on $\mathrm{A}_{\mathrm{CO} 2}$ from salinity stress were more important than the stomatal limitations on $\mathrm{A}_{\mathrm{CO} 2}$.

Elevated $\mathrm{CO}_{2}$ decreased leaf $\mathrm{Cl}^{-}$and $\mathrm{Na}^{+}$concentration in Carr but not in Cleo. This may have been attributable to decreased Ewp in Carr or to the increased S/R ratio and LDW/area. In previous studies, increasing shoot-to-root ratio by allowing part of the root system to dry out, decreased the amount of $\mathrm{Cl}^{-}$transported from roots to shoots in both Cleo and Carr under salinity stress (Moya et al., 2003). This supported their assumption that water and salt uptake were coupled. In our study, the lower leaf $\mathrm{Na}^{+}$and $\mathrm{Cl}^{-}$ concentrations in salinized Carr at $\mathrm{eCO}_{2}$ than at $\mathrm{aCO}_{2}$, were also related to the lower leaf transpiration rate. If transpiration is not essential for ion transport (Tanner and Beevers, 1990), however, it is unlikely that lower transpiration rates at $\mathrm{eCO}_{2}$ were solely responsible for the reduced ion uptake. The increased $\mathrm{S} / \mathrm{R}$ ratio for Carr plants could have resulted in a dilution of leaf $\mathrm{Cl}^{-}$and $\mathrm{Na}^{+}$concentrations relative to plants with low $\mathrm{S} / \mathrm{R}$ ratio. Our results were similar to those in tomato plants grown at $\mathrm{eCO}_{2}$, where limitations of root temperature and photon flux density interacted with salinity (Maggio et al., 2002). In all cases, the plant environment that produced the highest tolerance to root zone salinity also produced the highest $\mathrm{S} / \mathrm{R}$. In addition, growth in $\mathrm{eCO}_{2}$ increased LDW/a (also see Syvertsen et al., 2000) such that $\mathrm{Cl}^{-}$and $\mathrm{Na}^{+}$concentrations also could have been decreased by dilution in the higher LDW/area.

In salinized $\mathrm{Cleo}$, leaf $\mathrm{Cl}^{-}$, and $\mathrm{Na}^{+}$concentrations were similar in both $\mathrm{CO}_{2}$ treatments despite the lower leaf transpiration at $\mathrm{eCO}_{2}$. This may be related the opposite patterns of $\mathrm{Cl}^{-}$and $\mathrm{Na}^{+}$ accumulation in roots relative to their respective concentrations in leaves. In Carr, there were no significant differences in root 
$\mathrm{Cl}^{-}$and $\mathrm{Na}^{+}$between $\mathrm{aCO}_{2}$ and $\mathrm{eCO}_{2}$ but in $\mathrm{Cleo}$, root $\mathrm{Cl}^{-}$and $\mathrm{Na}^{+}$ were lower in $\mathrm{eCO}_{2}$ than in $\mathrm{aCO}_{2}$. There is an upper limit to the extent of $\mathrm{Cl}^{-}$loading in citrus roots (Cámara-Zapata et al., 2004; Walker and Douglas, 1983). This limit can be reached as soon as several days after commencing the salt treatment (FernandezBallester et al., 2003). In our experiment, the decrease in $\mathrm{Cl}^{-}$and $\mathrm{Na}^{+}$in roots of $\mathrm{Cleo}$ at $\mathrm{eCO}_{2}$ suggested that roots could lose their ability to regulate $\mathrm{Cl}^{-}$and $\mathrm{Na}^{+}$uptake even in the relatively $\mathrm{Cl}^{-}$ tolerant Cleo. Although leaf transpiration was lower at $\mathrm{eCO}_{2}$, the $\mathrm{Cl}^{-}$and $\mathrm{Na}^{+}$concentration in the xylem sap could have become more concentrated thereby achieving a similar balance of leaf $\mathrm{Cl}^{-}$and $\mathrm{Na}^{+}$concentration at both $\mathrm{CO}_{2}$ levels.

In nonsalinized Cleo plants, leaf $\mathrm{N}$ and $\mathrm{Ca}^{2+}$ concentrations also could have been reduced by a growth dilution effect $\mathrm{eCO}_{2}$. A similar decrease in leaf $\mathrm{N}$ occurred in both calomondin (Citrus madurensis Loureiro; Keutgen and Chen, 2001) and wheat (Triticum aestivum L.; Li et al., 2003) grown at $\mathrm{eCO}_{2}$ for 2 months. Elevated $\mathrm{CO}_{2}$ also can inhibit the assimilation of $\mathrm{NO}_{3}{ }^{-}$in shoots of $\mathrm{C}_{3}$ plants because this assimilation is strongly dependent on photorespiration which can be inhibited by $\mathrm{eCO}_{2}(\mathrm{Rachmilevitch}$ et al., 2004). Of all the macronutrients (N, P, K, Ca, Mg) studied in calamondin grown at $\mathrm{eCO}_{2}$ (Keutgen and Chen, 2001), only leaf $\mathrm{N}$ was decreased significantly by elevated $\mathrm{CO}_{2}$. In our experiment, a dilution of $\mathrm{N}$ due to enhanced plant growth at $\mathrm{eCO}_{2}$ cannot be ruled out because leaf $\mathrm{Ca}^{2+}$ was also reduced.

Under saline conditions, competition between $\mathrm{Cl}^{-}$and $\mathrm{NO}_{3}-\mathrm{N}$ uptake by roots may occur, which can decrease the $\mathrm{N}$ concentration in citrus leaves (Lea-Cox and Syvertsen, 1993). In our experiment, however, the increase in leaf $\mathrm{N}$ concentration of Cleo at $\mathrm{aCO}_{2}$ could have been due to a greater inhibition of shoot growth than of $\mathrm{NO}_{3}^{-}$uptake by salinity. This is supported by the fact that salinity increased $\mathrm{N}$ concentrations in roots of both genotypes regardless of the $\mathrm{CO}_{2}$ level. Cleo leaves had lower $\mathrm{Ca}^{2+}$ than Carr and salinity reduced $\mathrm{Ca}^{2+}$ further in $\mathrm{Cleo}$ at $\mathrm{aCO}_{2}$. This low $\mathrm{Ca}^{2+}$ could have been related to the high accumulation of leaf $\mathrm{Na}^{+}$in Cleo (Cámara et al., 2003). The concentrations of $\mathrm{Ca}^{2+}$ in roots were reduced by salinity in both genotypes regardless of the $\mathrm{CO}_{2}$ level. Thus, $\mathrm{Ca}^{2+}$ uptake was reduced by the $\mathrm{NaCl}$ treatment. Similar findings have been reported for salinized Cleo (Cámara et al., 2004; García-Sánchez et al., 2002; Syvertsen and Yelenosky, 1988) as high $\mathrm{Na}^{+}$in the soil solution can displace $\mathrm{Ca}^{2+}$.

In conclusion, $\mathrm{NaCl}$ salinity in the soil reduced plant growth of these citrus rootstock seedlings at both elevated and ambient levels of atmospheric $\mathrm{CO}_{2}$ concentrations. Elevated $\mathrm{CO}_{2}$ increased leaf growth in both nonsalinized plants and salinized plants. The increase in leaf dry weight at $\mathrm{CO}_{2}$ in Carr was higher for salinized plants than for nonsalinized plants. In Cleo, however, this $\mathrm{eCO}_{2}$ induced increase was similar at both salt levels. In Carr, $\mathrm{eCO}_{2}$ also reduced leaf $\mathrm{Na}^{+}$and $\mathrm{Cl}^{-}$concentration and leaf transpiration rates while increasing shoot-to-root ratio. Similar effects of $\mathrm{eCO}_{2}$ on $\mathrm{S} / \mathrm{R}$, leaf $\mathrm{Na}^{+}$and $\mathrm{Cl}^{-}$did not occur Cleo despite similar decreases in whole plant transpiration. Thus, $\mathrm{eCO}_{2}$ increased the salt tolerance of the relatively salt sensitive Carr more than that of in the more salt tolerant Cleo. In salinized seedlings of both genotypes, $\mathrm{Cl}$ - and $\mathrm{Na}^{+}$concentration changes in response to e $\mathrm{CO}_{2}$ in leaves vs. roots were generally in opposite directions. Thus, the modifications of citrus seedlings responses to salinity by the higher growth and lower water use at $\mathrm{eCO}_{2}$, not only depended on species specific salinity tolerance but also involved whole plant growth and allocation of $\mathrm{Na}^{+}$and $\mathrm{Cl}^{-}$.

\section{Literature Cited}

Ball, M.C. and R. Munns. 1992. Plant responses to salinity under elevated atmospheric concentrations of $\mathrm{CO}_{2}$. Austral. J. Bot. 40:515-525.

Bañuls, J. and E. Primo-Millo. 1992. Effects of chloride and sodium on gas exchange parameters and water relations of Citrus plants. Physiol. Plant. 86:115-123.

Bañuls, J.,F. Legaz, and E. Primo-Millo. 1990. Effect of salinity on uptake and distribution of chloride and sodium in some Citrus scion-rootstock combinations. J. Hort. Sci. 65:715-724.

Bowes, G. 1991. Growth at elevated $\mathrm{CO}_{2}$ : Photosynthesis responses mediated through Rubisco. Plant Cell Environ. 14:795-806.

Cámara, J.M., F. García-Sánchez, M. Nieves, and A. Cerdá. 2003. Effect of interstock ("Salustiano" orange) on growth, leaf mineral composition, and water relations of one-year-old citrus under saline condition. J. Hort. Sci. Biotechnol. 78:161-167.

Cámara-Zapata J.M., F. García-Sánchez, V. Martinez, M. Nieves, and A. Cerdá. 2004. Effect of $\mathrm{NaCl}$ on citrus cultivars. Agronomie 24:155-160.

Castle, W.S. and A.H. Krezdorn. 1975. Effect of citrus rootstocks on root distribution and leaf mineral content of Orlando tangelo trees. J. Amer. Soc. Hort. Sci. 100:1-4.

Chen, K. and F. Lenz. 1997. Responses of strawberry to doubled $\mathrm{CO}_{2}$ concentration and phosphorus deficiency II. Gas exchange and water consumption. Gartenbauwissenchaft 62:90-96.

Chen, Z.S. 1992. Identification of salt-tolerance of citrus germplasm. Acta Hort. Sinica 19:289-295.

Drake, A.M., M. Gonzalez-Meler, and S.P. Long. 1997. More efficient plants: A consequence of rising atmospheric $\mathrm{CO}_{2}$. Annu. Rev. Plant Physiol. Mol. Biol. 48: 607-637.

Farquhar, G.D. and T.D. Sharkey. 1982. Stomatal conductance and photosynthesis. Annu. Rev. Plant Physiol. Plant Mol. Biol. 33:317-345.

Fernández-Ballester, G., F. García-Sánchez, A. Cerdá, and V. Martínez. 2003. Tolerance of citrus rootstock seedlings to saline stress based on their ability to regulate ion uptake and transport. Tree Physiol. 23:265-271.

García-Legaz, M.F., J.M. Ortiz, A.G. García-Lidon, and A. Cerdá. 1993. Effect of salinity on growth, ion content and $\mathrm{CO}_{2}$ assimilation rate in lemon varieties on different rootstocks. Physiol. Plant. 89:427-432.

García-Sánchez, F., J. Jifon, M. Carvajal, and J.P. Syvertsen. 2002. Gas exchange, chlorophyll, and nutrient contents in relation to $\mathrm{Na}^{+}$and $\mathrm{Cl}$ accumulation in 'Sunburst' mandarin grafted on different rootstock. Plant Sci. 162:705-712.

Grattan, S.R. and C.M. Grieve. 1992. Mineral element acquisition and growth response of plants grown in saline environments. Agr. Ecosystem Environ. 38:275-300.

Hare P.D., W.A. Cress, and J. Van Staden. 1998. Dissecting the roles of osmolyte accumulation during stress. Plant Cell Environ. 21:535-553.

Inskeep, W.P. and P.R. Bloom. 1985. Extinction coefficients of chlorophyll a and b in $N, N$-dimethylformamide and $80 \%$ acetone. Plant Physiol. 77:483-485.

Jifon, J.L. and J.P. Syvertsen. 2003. Moderate shade can increase net gas exchange and reduce photoinhibition in citrus leaves. Tree Physiol. 23:119-127.

Keutgen, N. and K. Chen. 2001. Response of citrus photosynthesis, chlorophyll fluorescence, macronutrient, and carbohydrate contents to elevated $\mathrm{CO}_{2}$. J. Plant Physiol. 158:1307-1316.

Lea-Cox, J.D. and J.P. Syversten. 1993. Salinity reduces water use and nitrate-N-use efficiency of citrus. Ann. Bot. 72:47-54.

Levy, Y. and J. Syvertsen. 2004. Irrigation water quality and salinity effects in citrus trees. Hort. Rev. 30:37-82.

Li, F., S. Kang, J. Zhang, and S. Cohen. 2003. Effects of atmospheric $\mathrm{CO}_{2}$ enrichment, water status and applied nitrogen on water-and-nitrogenuse efficiencies of wheat. Plant Soil 254:279-289.

Lloyd, J., J.P. Syvertsen, and P.E. Kriedemann. 1987b. Salinity effects on leaf water relations and gas exchange of 'Valencia' orange [Citrus sinensis (L.) Osbeck] on rootstocks with different salt exclusion characteristics. Austral. J. Plant Physiol. 14:605-617. 
Lloyd, J.,P. Kriedemann, and D. Aspinall. 1990. Contrasts between Citrus species in response to salinization: An analysis of photosynthesis and water relations for different rootstock-scion combinations. Physiol. Plant. 78:236-246.

Lloyd, J., P.E. Kriedemann, and J.P. Syvertsen. 1987a. Gas exchange, water relations, and ion concentrations of leaves on salt-stressed 'Valencia' orange Citrus sinensis (L.) Osbeck. Austral. J. Plant Physiol. 14:387-396.

Maas, E.V. 1990. Crop salt tolerance, p. 262-304. In: K.K. Tanji (ed.). Agricultural salinity assessment and management. Amer. Soc. Civil Eng. Man. Rpts. Eng. No. 71, ASCE, New York.

Maggio, A., F.N. Dalton, and G. Piccinni. 2002. The effect of elevated carbon dioxide on static and dynamic indices for tomato salt tolerance. Eur. J. Agron. 16:197-206.

Maxwell, K. and G.N. Johnson. 2000. Chlorophyll fluorescence-A practical guide. J. Expt. Bot. 51:659-668.

Moya, J.L., A. Gomez-Cadenas, E. Primo-Millo, and M. Talon. 2003. Chloride absorption in salt-sensitive Carrizo citrange and salt-tolerant Cleopatra mandarin citrus rootstocks is linked to water use. J. Expt. Bot. 54:825-833.

Moya, J.L., E. Primo-Millo, and M. Talon. 1999. Morphological factors determining salt tolerant in citrus seedlings: The shoot to root ratio modulates passive root uptake of chloride ions and their accumulation in leaves. Plant, Cell Environ. 22:1425-1433.

Munns, R. 1993. Physiological processes limiting plant growth in saline soils: Some dogmas and hypotheses. Plant Cell Environ. 16:15-24.

Nicolas, M.E., R. Munns, A.B, Samarakoon, and R.M. Gifford. 1993. Elevated $\mathrm{CO}_{2}$ improves the growth of wheat under salinity. Austral. J. Plant Physiol. 20:349-360.

Rachmilevitch, S., A.B. Cousins, and A.J. Bloom. 2004. Nitrate assimilation in plants shoots depends on photorespiration. Proc. Natl. Acad. Sci. 101:11506-11510.

Scholander, P., H. Hammel, E. Bradstreet, and E. Hemmingsen. 1965.
Sap pressure in vascular plants. Science 148:339-345.

Shalhevet, J. and Y. Levy. 1990. Citrus trees, p. 951-986. In: B.A. Stewart and D.R. Nielsen (eds.). Irrigation of agricultural crops. Amer. Soc. Agron. Madison, Wis.

Syvertsen, J.P. and G. Yelenosky. 1988. Salinity can enhance freeze tolerance of citrus rootstock seedlings by modifying growth, water relations, and mineral nutrition. J. Amer. Soc. Hort. Sci. 113:889-893.

Syvertsen, J.P. 1984. Light acclimation in citrus leaves. II. $\mathrm{CO}_{2}$ assimilation and light, water and nitrogen use efficiency. J. Amer. Soc. Hort. Sci. 109:812-817.

Syvertsen, J.P., B. Boman, and D.P.H. Tucker. 1989. Salinity in Florida citrus production. Proc. Fla. State Hort. Soc. 102:61-64.

Syvertsen. J.P., L.S. Lee, and J.W. Grosser. 2000. Limitations on growth and net gas exchange of diploid and tetraploid citrus rootstock cultivars grown at elevated $\mathrm{CO}_{2}$. J. Amer. Soc. Hort. Sci. 125:228-234.

Tanner, W. and H. Beevers. 1990. Does transpiration have an essential function in long-distance transport in plants? Plant Cell Environ. 13:745-750.

Walker, R.R. and T.J. Douglas. 1983. Effect of salinity level on uptake and distribution of chloride, sodium and potassium ions in citrus plants. Austral. J. Agr. Res. 34:145-153.

Walker, R.R., D.H. Blackmore, and Qing Sun. 1993. Carbon dioxide assimilation and foliar ion concentrations in leaves of lemon (Citrus limon L.) trees irrigated with $\mathrm{NaCl}$ or $\mathrm{Na}_{2} \mathrm{SO}_{4}$. Austral. J. Plant. Physiol. 20:173-185.

Yelle, S., R.C. Beeson Jr., M.J. Trudel, and A. Gosselin. 1989. Acclimation of the tomato species to high atmospheric $\mathrm{CO}_{2}$. Ribulose-1,5-biphosphate carboxylase/oxygenase and phosphoenol-pyruvate carboxylase. Plant Physiol. 90:1473-1477.

Yeo A.R. 1998. Molecular biology of salt tolerance in the context of whole plant physiology. J. Expt. Bot. 49:915-929.

Zekri, M. 1991. Effects of NaCl on growth and physiology of sour orange and Cleopatra mandarin seedlings. Sci. Hort. 47:305-315. 